\title{
ANALISIS KARAKTERISTIK PARKIR SEPEDA MOTOR DI KAWASAN PUSAT PERBELANJAAN GARUDA MITRA KOTA PONTIANAK
}

\author{
Syafaruddin As 1, Heri Azwansyah 1, Sutarto YM 1 \\ ${ }^{1}$ Kelompok Keahlian Rekayasa Transportasi, Universitas Tanjungpura, Pontianak, Indonesia
}

\begin{abstract}
Abstrak
Studi ini bertujuan untuk mengetahui karakteristik parkir kendaraan sepeda motor pada kawasan Swalayan Garuda Mitra Pontianak. Metode survey yang dilakukan adalah dengan pengamatan lapangan dan pencatatan kendaraan masuk dan keluar lahan parkir. Analiis dilakukan untuk mendapatkan karakteristik parkir kendaraan yaitu jumlah kendaraan masuk dan keluar dari lahan parkir, durasi kendaraan, akumulias, volume parkir, tingkat pergantian, dan tingkat penggunaan lahan parkir.

Hasil penelitian ini antara lain volume total parkir kendaraan dalam satu hari sebanyak 1.085 kendaraan. Akumulias parkir yang terbesar berada pada pukul 17.31 - 18.00 WIB yaitu sebanyak 153 kendaraan. Tingkat penggunaan lahan parkir terbesar pada pukul 19.01 - 20.00 WIB sekitar 43,78\% dari kapasitas parkir yang tersedia. Permasalahan dilapangan adalah pengaturan parkir yang relatif kurang baik sehinga pemanfaatan lahan parkir yang tidak optimal, terutama tata latak parkir dan sirkulasi kendaraan pada lahan parkir.
\end{abstract}

Katakunci : Volume Parkir, Akumulasi Parkir, Tingkat Penggunaan Parkir, Pengaturan Parkir

\begin{abstract}
This study aims to determine the characteristics of motorcycle parking in the Garuda Mitra of Pontianak City. The survey method carried out was by field observation and recording of vehicles entering and leaving the parking lot. Analysis was carried out to obtain the characteristics of vehicle parking, namely the number of vehicles entering and leaving the parking lot, the duration of the vehicle, accumulation, parking volume, turnover rate, and level of use of parking lots.

The results of this study include the total volume of vehicle parking in one day as many as 1,085 vehicles. The biggest parking accumulations are at 17:31 - 18:00 WIB which is 153 vehicles. The highest level of parking space usage is at $19.01-20.00$ WIB around $43.78 \%$ of the available parking capacity. The problem in the field is that parking arrangements are relatively inadequate so that the utilization of the parking lot is not optimal, especially in the parking system and vehicle circulation in the parking lot.
\end{abstract}

Keywords:Parking Volume, Parking Accumulation, Parking Usage Rate, Parking Arrangement

\section{Pendahuluan}

Parkir merupakan salah satu unsur sarana yang tidak dapat dipisahkan dari sistem transportasi jalan raya secara keseluruhan. Seiring dengan perkembangan zaman, tingkat kebutuhan sarana dan prasarana transportasi masyarakat mengalami peningkatan dikarenakan keinginan masyarakat untuk bepergian ke tempat-tempat yang di tujunya (Yuda, 2015). Dengan meningkatnya jumlah penduduk suatu kota akan menyebabkan meningkatnya kebutuhan

\footnotetext{
${ }^{*}$ Heri Azwansyah

E-mail: heriazwansyah@civil.untan.ac.id
}

melakukan berbagai macam kegiatan. Kebanyakan penduduk di kota-kota besar melakukan kegiatan atau berpergian dengan menggunakan kendaraan pribadi sehingga secara tidak langsung di perlukan jumlah lahan parkir yang memadai.

Perparkiran bukanlah suatu fenomena yang baru. Perparkiran merupakan masalah yang sering dijumpai dalam sistem transportasi perkotaan, baik di kota-kota besar maupun kota yang sedang berkembang (Sholikhin, dkk., 2017). Masalah perparkiran tersebut akhir-akhir ini terasa sangat mempengaruhi pergerakan kendaraan, di mana kendaraan yang melewati tempat - tempat yang mempunyai aktivitas tinggi, laju pergerakaan nya akan terhambat oleh kendaraan yang parkir di badan jalan. 
Pada umumnya kendaraan yang parkir di pinggir jalan berada sekitar tempat atau pusat kegiatan seperti : perkantoran, sekolah, pusat kegiatan ekonomi (pasar swalayan, bioskop, rumah makan), dan lain - lain. Dalam rangka mengatasi permasalahan tersebut, maka diperlukan, pengadaan lahan parkir yang cukup. Kebutuhan lahan parkir (demand) dan prasarana yang akan dibutuhkan (supply) harus seimbang dan disesuaikan dengan karakteristik perparkiran.

Swalayan Garuda Mitra merupakan salah satu pusat perbelanjaan modern di Kota Pontianak. Pusat perbelanjaan ini berada di sisi jalan utama di Kota Pontianak tepatnya di sisi Jalan H. Rais A. Rahman. Kawasan ini berada salah satu pusat kegiatan masyarakat Kota Pontianak. Lokasinya yang sangat strategis berada pada kawasan perdagangan dan pemukiman yang padat penduduk, menjadikan kawasan ini relatif banyak dikunjungi oleh masyarakat.

Tingginya intensitas aktivitas pengunjung yang menggunakan kendaraan pribadi sepeda motor menuntut tersedianya fasilitas perparkiran yang memadai. Sistem perparkiran yang tidak sesuai kebutuhan maka akan berdampak pada luapan parkir di badan jalan yang selanjutya akan mengakibatkan gangguan kelancaran lalu lintas di sekitar kawasan tersebut.

Disisi lain, kurang optimalnya pengelolaan parkir juga terlihat dari pelayanan parkir yang sangat jauh dari rasa nyaman dan memuaskan. Banyaj pengguna parkir yang mengeluhkan dengan kualitas layanan parkir yang diberikan (Taruno, 2017).

Berdasarkan uraian diatas maka penelitian ini diangkat dengan tujuan untuk mengetahui karakteristik parkir yang ada di kawasan Swalayan Garuda Mitra Pontianak.

\section{Studi Pustaka}

\subsection{Pengertian Dasar Kebutuhan Parkir}

Parkir dapat diartikan sebagai tempat pemberhentian kendaraan beberapa saat (tamin 2000 dalam Novier, dkk 2015). Sarana perparkiran ialah merupakan suatu bagian dari sistem transportasi dalam perjalanan untuk mencapai suatu tujuan, karena dalam setiap proses perjalanan, setiap kendaraan harus diparkir ketika penumpang ataupun pengemudi harus melakukan kativitas di luar kendaraan tersebut. Oleh sebab itu jalan tempat parkir sangat dibutuhkan dalam sistem lalu lintas.

Beberapa pengertian mengenai tempat parkir yang relatif sama, yakni :

- Parkir adalah tempat memberhentikan kendaraan angkutan/ barang (bermotor maupun tidak bermotor) pada suatu tempat dalam jangka waktu tertentu.

- Parkir adalah tempat pemberhentian kendaraan dalam jangka waktu yang relatif lama atau sebentar tergantung kendaraan dan kebutuhan nya ( di kutip dari buku Peraturan Lalu - lintas )
- Parkir adalah berhentinya kendaraan untuk beberapa saat atau dalam jangka waktu yang lama sesuai dengan kebutuhan pengendaraannya.

Maka secara sederhana kebutuhan parkir di artikan sebagai kebutuhan akan lahan untuk memarkir sejumlah kendaraan selama jangka waktu tertentu.

\subsection{Kebutuhan Akan Tempat Parkir}

Masalah parkir adalah masalah kebutuhan ruang. Penyediaan ruang dalam kota di batasi oleh luas wilayah kota yang ada dan tata guna tanahnya. Pengadaan pelataran parkir sedikit banyak akan menyita sebagian luas wilayah kota karena pelataran parkir membutuhkan ruang tersendiri yang cukup luas. Penggunanya sendiri belum tentu selalu maksimum, melainkan bergantung pada jam sibuk.

Apabila ini dilakukan pada hari libur, kebutuhan tertinggi akan pelataran parkir dapat ditaksir. Penelitian lebih lanjut dapat dilakukan pada tempat yang sama pada pukul 09.00, yang akan memberi petunjuk tentang tuntutan kebutuhan pelataran lahan parkir bagi kepentingan pengunjung.

Perhitungan penggunaan pelataran parkir dalam satu hari penuh menjadi ukuran kebutuhan perusahaan dan perdagangan akan pelataran parkir, sementara perhitungan pada hari sabtu petang menujukkan kebutuhan perbelanjaan akan hal yang sama.

Luas yang dibutuhkan untuk peralatan parkir bergantung pada dua hal pokok, yaitu ukuran kendaraan yang di perkirakan parkir dan sudut parkir. Parkir dibutuhkan oleh berbagai pihak dan dalam pengadaan tempat parkir perlu diperhatikan keragaman tuntutan atau keinginan para pelaku lalu lintas yang cenderung saling berebutan.

Pemerintah (dalam hal ini ahli perlalu - lintasan) dituntut agar sedapat mungkin mengusahakan keseimbangan berbagai keinginan tersebut.

Tabel 1. Keinginan akan sarana parkir

\begin{tabular}{|l|l|}
\hline \multicolumn{1}{|c|}{ Pelaku Lalu - Lintas } & \multicolumn{1}{c|}{ Keinginan } \\
\hline Perorangan ( peparkir ) & $\begin{array}{l}\text { Bebas, mudah mencapai tempat } \\
\text { tujuan. } \\
\text { Pudah bongkar muat. } \\
\text { Menyenangkan pembeli. }\end{array}$ \\
Kendaraan umum & $\begin{array}{l}\text { Dikhususkan, terpisah supaya aman } \\
\text { untuk naik - turun penumpang. } \\
\text { Mudah keluar - masuk agar dapat } \\
\text { menempati jadwal perjalanan. } \\
\text { Mudah bongkar muat. }\end{array}$ \\
Kendaraan barang & $\begin{array}{l}\text { Bisa parkir berjejer bila perlu. } \\
\text { Bebas parkir, tanpa hambatan. } \\
\text { Parkir bebas. }\end{array}$ \\
Kendaraan yang bergerak \\
Pengusaha parkir \\
(pemarkir )
\end{tabular}


\begin{tabular}{|l|l|}
\hline & $\begin{array}{l}\text { Mengusahakan melancarkan } \\
\text { lalulintas. }\end{array}$ \\
\hline
\end{tabular}

Sumber : Muktyarso dan Herijanto, 2018

\subsection{Jenis Parkir}

Menurut Khisty dan Lall (2005) dikutip dari Awaliah (2008), jenis penataan sarana parkir di klasifikasikan menurut penempatannya terbagi dua yaitu:

\section{a. Parkir di badan jalan (on - street parking)}

Parkir di badan jalan mengambil tempat di sepanjang jalan dengan atau tanpa melebarkan jalan untuk pembatas parkir dan bagi pengunjung jenis parkir ini sangat dirugikan kalau tidak diatur dengan baik juga untuk lokasi dengan intensitas penggunaan lahan tinggi kurang menguntungkan sebab :

- Menggangu kelancaran arus lalu lintas

- Berkurangnya lebar jalan menyebabkan berkurangnya kapasitas jalan

- Menimbulkan kemacetan lalu lintas

b. Parkir di luar badan jalan (off-street parking)

Cara parkir ini menempati peralatan parkir tertentu baik dihalaman terbuka maupun didalam bangunan khusus dan direncanakan berdasarkan standar yang berlaku serta tidak menggunakan badan jalan. Posisi parkir dapat dilakukan seperti on street parking hanya pengaturan sudut parkir dipengaruhi luas dan bentuk peralatan parkir. Off street parking diharapkan dapat memberikan tingkat keamanan lebih baik dari perusakan dan pencurian.

Sedangkan menurut jenis kendaraan yang parkir, terdapat beberapa golongan parkir yaitu :

- Parkir untuk kendaraan beroda dua tidak bermesin (sepeda)

- Parkir untuk kendaraan beroda dua bermesin (sepeda motor)

- Parkir untuk kendaraan beroda tiga, empat, atau lebih bermesin (bemo, mobil)

Pemisahan tempat parkir menurut jenisnya mempunyai tujuan agar pelayanan lebih mudah dan agar tidak terjadi keruwetan dan antar kegiatannya tidak saling menunggu.

\subsection{Layout Parkir}

Tata letak parkir dituntut agar dalam melakukan pakir kedaraan dapat bergerak secara tepat, mudah, nyaman dan aman baik pergerakan keluar maupun saat pada akan masuk. Sehingga pengendara mobil diharapkan tidak merasa terhambat disaat mau melakukan pergerakan dan tidak membahayakan kendaraan lain yang ada disekitarya. Luas areal parkir yang terlalu besar akan menciptakan banyak ruang kosong dan tidak terisi sehingga menjadi kurang efisien dalam hal pemanfaatan ruang, dan sebaliknya. Maka tata letak parkir juga disesuaikan dengan ketersediaan lahan, sehingga tercapai kapasitas parkir yang optimum. Layout parkir dipengaruhi oleh beberapa hal, yaitu :

Menurut Baker dan Funaro (2007) dikutip dari Awaliah (2008), ada 3 hal penting di dalam menentukan layout yaitu :

\section{Panjang dan lebar ruang parkir}

Panjang dan lebar ruang parkir sangat tergantung dari tipe kendaraan yang digunakan. Kendaraan mempunyai ukuran yang beraneka ragam, menurut British Parking Association Technical Committee ukuran panjang 4,75 m dengan lebar 2,5 m. Ukuran ini sudah diperhitungkan bila pintu kendaraan dibuka.

\section{Lebar jalan akses}

Lebar jalan akses sangat dipengaruhi lebar ruang parkir. Menambah ruang parkir akan mempersempit lebar jalan akses. Desain tempat parkir serta gang yang dibuat harus didasarkan pada ukuran kendaraan sedangkan lebar gang yang diperlukan berbeda-beda tergantung sudut kendaraan yang diparkir karena makin kecil sudut antara akses yang diparkir maka akan lebih kecil ruang yang dibutuhkan. Bangunan parkir yang mempunyai kolom pendukung, gang dan ruang harus disesuaikan sehingga kendaraan tersebut dapat bergerak maupun manuver dengan mudah. Karakteristik lainnya yang perlu diperhatikan adalah penentuan ukuran pintu gerbang kendaraan masuk / keluar.

\subsection{Pemilihan sudut parkir}

Pemilihan sudut parkir berdasarkan tempat atau dengan tujuan pemarkir merasa nyaman saat parkir tanpa hambatan. Untuk sudut $30^{\circ}$ jarang dilakukan karena hampir sama dengan posisi sejajar sumbu jalan. Posisi parkir yang banyak digunakan adalah sudut parkir $60^{\circ}$ karena posisi sudut ini lebih banyak ruang parkir bila dibandingkan dengan posisi sejajar jalan dan tidak mengurangi lebar jalan akses. Sudut parkir $90^{\circ}$ kurang disenangi pengemudi karena pergerakan manuver cukup sulit dan sudut ini menyita lebar jalan akses, sudut parkir $45^{\circ}$ biasanya dilakukan dengan kondisi overlap dengan memanfaatkan ruang kosong.

\subsection{Tarif parkir}

Tarif parkir adalah biaya yang harus dikeluarkan atau dibayarkan oleh pemilik kendaraan selama memarkir kendaraannya pada suatu lahan parkir tertentu. Dimana jenis pembayaran parkir adalah :

1. Parkir tanpa tarif atau parkir bebas (Free parking ) Parkir pada badan jalan pada umumnya merupakan parkir garis atau parkir yag tidak dipungut biaya. Namun pada tempat-tempat tertentu terdapat pengecualian, yang dimaksudkan untuk membatasi waktu parkir dan lamanya kendaraan parkir. Sedangkan pada off street parking dapat berupa 
fasilitas umum atau dapat juga milik atau disewa oleh suatu perusahaan swasta atau BUMN kemudian memberikan fasilitas parkir Cuma -Cuma untuk pekerjaannya selama jam kerja, kunjungan kerja, dan untuk kendaraan komersial.

2. Parkir dengan tarif (Fee paying parking)

Umumnya para pengguna jasa parkir pada saat perbelanjaan biasanya diharuskan membayar tarif parkir. Sistem pentarifan parkir dapat dibedakan sebagai berikut :

a. Sistem tetap : sistem pembayaran besaran tarif yang tidak membedakan lama parkir suatu kendaraan.

b. Sistem berubah sesuai waktu (progesif) : sistem pembayaran besaran tarif yang merupakan lam awaktu parkir suatu kendaraan.

c. Sistem kombinasi : sistem pembayaran besaran tarif yang mengkombinasikan kedua sistem diatas.

\subsection{Metode menentukan kebutuhan ruang parkir}

Untuk menentukan jumlah ruang parkir dapat digunakan metode :

1. Metode yang menitik beratkan pada kepemilikan kendaraan

Metode ini menjelaskan adanya hubungan antara luas lahan parkir dengan jumlah kendaraan yang tercatat di pusat kota. Semakin meningkat jumlah penduduk maka kebutuhan lahan parkir akan semakin meningkat karena kepemilikan kendaraan meningkat sementara persentasi ruang parkir yang dibutuhkan semakin menurun (Tamin, 2008).

2. Metode berdasarkan luas lantai bangunan

Metode ini mengasumsikan bahwa kebutuhan lahan parkir sangat terkait dengan jumlah kegiatan yang dinyatakan dalam besaran luas lantai bangunan dimana kegiatan tersebut dilakukan, misalnya: perbelanjaan, perkantoran, dan lain - lain. Setiap luas areal yang tersedia berdasarkan hasil studi yang telah dilakukan di butuhkan ruang parkir yang berbeda - beda antara kegiatan satu dengan yang lainnya ( tataguna lahan tunggal).

Ada beberapa lokasi dimana sejumlah tataguna lahan dalam lokasi yang berdekatan. Daerah ini disebut area tataguna lahan campuran dan cenderung menunjukan karakteristik yang berbeda dengan pengembangan tataguna lahan tunggal. Kebutuhan parkir untuk tatagun lahan campuran telah dikutip oleh YOUNG (1990), untuk memperkirakan kebutuhan parkir di tataguna lahan campuran dengan menggunakan batasan:

- Ruang per pekerja 1,00 m sampai 1,05 m.

- Ruang per pelajar setempat $0,5 \mathrm{~m}$ sampai $0,55 \mathrm{~m}$.

- Ruang per pelajar yang tidak tinggal di daerah tersebut $0,35 \mathrm{~m}$ sampai $0,40 \mathrm{~m}$.
- Ruang per pengunjung umum 1 per $28 \mathrm{~m}$ sampai 1 per $26 \mathrm{~m}$.

3. Metode berdasarkan selisih terbesar antara kedatangan dan keberangkatan kendaraan (akumulasi maksimum)

Akumulasi parkir adalah jumlah kendaraan parkir pada suatu tempat pada selang waktu tertentu, di mana Jumlah kendaraan parkir tidak akan sama pada suatu tempat dengan tempat lainnya dari waktu ke waktu. Kebutuhan parkir di cari dengan cara mendapatkan akumulasi maksimum dari suatu interval pengamatan. Akumulasi dan studi bangkitan dibuat untuk menentukan puncak parkir pada interval yang relatif sering dalam hari yang berbeda pada satu minggu dimana jam - jam, hari - hari, bulan - bulan tersibuk harus diketahui.

Analisa akumulasi di lakukan dengan perhitungan kendaraan yang bergerak masuk dan keluar yang dilakukan terus - menerus, cara ini memerlukan pengetahuan jumlah kendaran pada fasilitas di awal perhitungan dan pengecekan jumlah kendaraan yang tersisa pada akhir perhitungan agar menjelaskan keakuratan perhitungan.

\subsubsection{Pengukuran Parkir}

Merupakan upaya untuk mengetahui dalam berbagai segi aspek perparkiran dalam rangka untuk menunjang perparkiran kemampuan pemanfaatan perparkiran. Maksud pengukuran ini adalah dalam rangka untuk manajemen dengan sebaik mungkin agar dalam pelayanan akan perparkiran semakin baik.

Hal - hal utama dalam pengukuran yang di gunakan dalam survey adalah:

1. Akumulasi parkir

Informasi ini sangat dibutuhkan untuk mengetahui jumlah kendaraan yang sedang berada pada suatu lahan parkir pada selang waktu tertentu. Informasi ini dapat diperoleh dengan cara menjumlahkan kendaraan yang telah menggunakan lahan parkir ditambah dengan kendaraan yang masuk serta dikurangi dengan kendaraan yang keluar.

2. Volume parkir

Menyatakan jumlah kendaraan yang telah menggunakan ruang parkir pada suatu lahan parkir tertentu dalam satu satuan waktu tertentu (biasanya per hari). Waktu yang digunakan kendaraan untuk parkir, dalam menitan atau jam - jaman, menyatakan lama parkir.

3. Pergantian parkir (parking turn - over) dan tingkat penggunaan (occupancy rate)

Menunjukan tingkat pergantian diperoleh dari jumlah kendaraan yang telah memanfaatkan lahan parkir pada selang waktu tertentu dibagi dengan ruang parkir yang tersedia. Sedangkan, tinggat penggnaan diperoleh dari akumulasi kendaraan pada 
selang waktu tertentu dibagi dengan ruang parkir yang tersedia dikalikan dengan $100 \%$.

3. Indeks Parkir

Merupakan persentase dari akumulasi jumah kendaraan pada selang waktu tertentu dibagi dengan ruang parkir yang tersedia dikalikan $100 \%$.

4. Kapasitas Parkir

Banyaknya kendaraan yang dapat dilayani oleh suatu lahan parkir selama waktu pelayanan.

5. Durasi Parkir

Informasi ini sangat dibutuhkan untuk mengetahui lama suatu kendatraan untuk parkir. Informasi inidiperoleh dengan cara mengamati waktu kendaraan masuk dan waktu kendaraan tersebut keluar, selisih dari waktu tersebut adalah durasi parkir.

\subsubsection{Standar Tempat Parkir}

Kebutuhan tempat parkir untuk kendaraan baik kendaraan pribadi maupun angkutan penumpang umum, sepeda motor maupun truk adalah sangat penting. Kebutuhan tersebut sangat berbeda dan bervariasi tergantung dari bentuk dan karakteristik masing masing kendaraan dengan desain dan standar parkir harus memenuhi kriteria. Standar tempat parkir sangatlah penting dalam melakukan parkir kendaraan agar dapat dengan mudah bergerak secara cepat baik pergerakan keluar maupun pada saat akan masuk.

Dalam hal penentuaan tempat parkir digunakan suatu satuan yaitu Satuan Ruang Parkir (SRP). Satuan Ruang Parkir (SRP) adalah ukuran luas efektif untuk meletakan kendaraan (mobil penumpang, bus / truk, atau sepeda motor), termasuk ruang bebas dan lebar bukaan pintu.

Adapun satuan ruang parkir untuk masing masing jenis kendaraan menurut standar Dir. Jend. Bina Marga adalah sebagai berikut:

1. Bus/Truk : $3,40 \times 12,50\left(\mathrm{~m}^{2}\right)=42,5 \mathrm{~m}^{2}$

2. Mobil penumpang : $2,50 \times 5,00\left(\mathrm{~m}^{2}\right)=12,50 \mathrm{~m}^{2}$

3. Sepeda motor : $0,75 \times 2,00\left(\mathrm{~m}^{2}\right)=1,5 \mathrm{~m}^{2}$ Besarnya ruang parkir dipengaruhi oleh:

\section{a. Dimensi kendaraan standar}

Dalam lingkup studi ini, dimensi kendaraan yang dimaksud adalah untuk mobil penumpang dengan menggunakan standar dimensi kendaraan mobil penumpang yang dikeluarkan oleh Dit. Jend. Bina Marga, Departemen Pekerjaan Umun.

Adapun dimensi kendaraan mobil penumpang tersebut adalah (Bina Marga, 1992) :

Panjang $(\mathrm{L})=4,7 \mathrm{~m}$

Lebar total $(\mathrm{d}) \quad=1,7 \mathrm{~m}$

Tinggi $(\mathrm{h})=2,0 \mathrm{~m}$

Depan tergantung $=0,8 \mathrm{~m}$

Belakang tergantung $=1,2 \mathrm{~m}$

Jarak gandar $=2,7 \mathrm{~m}$

Radius putar minimum $=6,0 \mathrm{~m}$

\section{b. Ruang bebas arah lateral dan memanjang}

Ruang bebas kendaraan parkir diberikan pada arah lateral dan memanjang. Ruang bebas lateral ditetapkan pada saat posisi pintu kendaraan dibuka, yang diukur dari ujung terluar pintu kebadan kendaraan parkir yang ada disampingnya. Ruang bebas ini diberikan agar tidak terjadi benturan antara pintu kendaraan dengan kendaraan yang di parkir disampingnya pada saat penumpang turun dari kendaraan, sedangkan ruang bebas arah memanjang diberikan di depan kendaraan untuk menghindari benturan dengan dinding atau kendaraan yang diparkir didepan dan dibelakanng kendaraan untuk menghindari benturaan kendaraan yang lewat jalur gang.

Perhitungaan ruang bebas ini selain dipergunakaan untuk merencanakan ruang parkir terbuka juga dapat dimanfaatkan pada saat orang mendesain garasi kendaraan dirumah sehingga didapatkan ukuran yang optimal dengan menghemat ruangan dan aman untuk memarkir kendaraan. Apabila hal ini tidak diperhatikan maka akan berdampak menjadi fatal yaitu sering terjadinya kendaraan menabrak dinding atau pembatas dan akan memerlukan biaya besar untuk perbaikan mobilnya.

\section{Metodologi}

\subsection{Lokasi Penelitian}

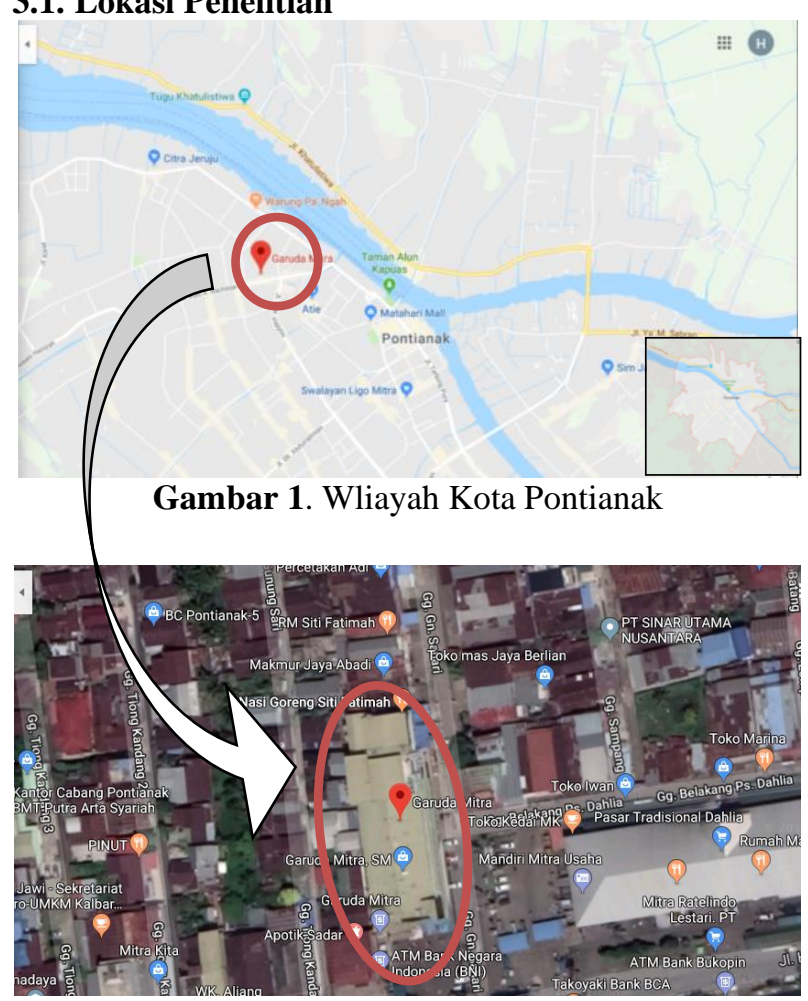

Gambar 2. Lokasi Garuda Mitra 
Penelitian ini mengambil lokasi di Swalayan Garuda Mitra Jl. H. Rais A Rahman Kota Pontiana.

\subsection{Teknik Pengumpulan Data}

Pengumpulan data dilakukan dengan dua cara,yaitu observasi dan studi dokumenter.

1. Cara Observasi / Pengenalan Lapangan

Metode observasi adalah suatu pengumpulan data yang didapat melalui pengamatan dan pencatatan gejala yang tampak pada objek penelitian yang dilakukan secara langsung atau tidak lagsung di lapangan dimana suatu peristiwa, keadaan atau suatu yang sedang terjadi.

2. Cara Studi Dokumenter / Studi Pustaka

Metode studi dokumenter adalah suatu cara pengumpulan data yang dikumpulkan didapat dari sumber maupun literatur-literatur serta berbagai tulisan yang berhubungan dengan masalah yang akan diteliti.

Data - data yang dibutuhkan untuk penelitian ini ialah :

a. Data Primer

Data primer merupakan data yang didapat langsung dari lapangan dengan mengadakan survey lapangan yaitu survey pada tempat parkir pada Pasar Swalayan Garuda Mitra Pontianak.

Adapun survey yang akan dilakukan antara lain :

1) Survey kondisi lahan parkir dan fasilitas parkir

2) Survey waktu masuk dan keluar kendaraan

b. Data Sekunder

Data sekunder merupakan data penunjang yang diperoleh dari badan atau instansi - instansi yang terkait erat hubungannya dengan penelitian yang akan dilakukan.

Adapun data sekunder yang dibutuhkan antara lain : Data luas lahan parkir

\section{Hasil dan Pembahasan}

\subsection{Durasi dan Pendapatan Parkir}

Durasi parkir adalah lamanya suatu kendaraan yang parkir pada suatu lahan tertentu. Nilai durasi parkir diperoleh dari selisih antara waktu keluar kendaraan dengan waktu masuk kendaraan pada suatu lahan tertentu.

Berikut hasil pengolahan data durasi parkir dari yang diamati:

Tabel 1. Durasi Parkir

\begin{tabular}{|c|c|c|}
\hline No & Durasi Parkir & Jumlah Kendaraan \\
\hline 1 & $0-30$ & 654 \\
\hline 2 & $31-60$ & 267 \\
\hline 3 & $61-90$ & 133 \\
\hline 4 & $91-120$ & 31 \\
\hline & Total & 1085 \\
\hline
\end{tabular}

Sumber : Analisis Data, 2017
Tabel 1 memperlihatkan durasi parkir sepeda motor di Garuda Mitra. Lamanya parkir kendaraan (Durasi) dominan pada waktu 0 - 30 menit dengan jumlah kendaraan 654 kendaraan, Selanjutnya lamanya parkir kendaraan (Durasi) pada waktu $31-60$ menit sebanyak 267 kendaraan.

Diketahui bahwa tarif parkir diterapkan tarif tetap yaitu sebesar Rp. 1.000 perkendaraan. Dengan volume kendaraan sebesar 1.085 kendaraan maka dapat ditentukan penerimaan parkir selama satu hari adalah

Pendapatan Parkir $=$ Vol. parkir $\mathrm{x}$ Tarif parkir

$$
=1.085 \times \text { Rp. } 1.000
$$$$
=\text { Rp. } 1.085 .000
$$

\subsection{Karekteristik Kedatangan, Keberangkatan, Akumulasi dan Volume Parkir}

Tabel 2. Waktu Parkir, Jumlah Kendaraan Masuk dan Keluar Parkir

\begin{tabular}{|c|c|c|c|c|c|}
\hline No & Waktu & Masuk & Keluar & Akumulasi & Volume \\
\hline 1 & $<09.00$ & 0 & & 0 & 0 \\
\hline 2 & $09.01-09.30$ & 38 & 18 & 20 & 38 \\
\hline 3 & $09.31-10.00$ & 28 & 12 & 36 & 66 \\
\hline 4 & $10.01-10.30$ & 33 & 18 & 51 & 99 \\
\hline 5 & $10.31-11.00$ & 64 & 32 & 83 & 163 \\
\hline 6 & $11.01-11.30$ & 39 & 21 & 101 & 202 \\
\hline 7 & $11.31-12.00$ & 37 & 54 & 84 & 239 \\
\hline 8 & $12.01-12.30$ & 33 & 34 & 83 & 272 \\
\hline 9 & $12.31-13.00$ & 28 & 21 & 90 & 300 \\
\hline 10 & $13.01-13.30$ & 15 & 37 & 68 & 315 \\
\hline 11 & $13.31-14.00$ & 31 & 17 & 82 & 346 \\
\hline 12 & $14.01-14.30$ & 52 & 26 & 108 & 398 \\
\hline 13 & $14.31-15.00$ & 40 & 44 & 104 & 438 \\
\hline 14 & $15.01-15.30$ & 45 & 30 & 119 & 483 \\
\hline 15 & $15.31-16.00$ & 73 & 78 & 114 & 556 \\
\hline 16 & $16.01-16.30$ & 47 & 48 & 113 & 603 \\
\hline 17 & $16.31-17.00$ & 66 & 46 & 133 & 669 \\
\hline 18 & $17.01-17.30$ & 74 & 54 & 153 & 743 \\
\hline 19 & $17.31-18.00$ & 38 & 76 & 115 & 781 \\
\hline 20 & $18.01-18.30$ & 60 & 71 & 104 & 841 \\
\hline 21 & $18.31-19.00$ & 55 & 61 & 98 & 896 \\
\hline 22 & $19.01-19.30$ & 63 & 62 & 99 & 959 \\
\hline 23 & $19.31-20.00$ & 55 & 81 & 73 & 1014 \\
\hline 24 & $20.01-20.30$ & 36 & 75 & 34 & 1050 \\
\hline 25 & $20.31-21.00$ & 35 & 69 & 0 & 1085 \\
\hline
\end{tabular}

Sumber : Analisis Data, 2017

Tabel 2 memperlihatkan Waktu parkir, jumlah kendaraan masuk dan keluar dari lahan parkir Garuda Mitra, diketahui bahwa jumlah kendaraan yang masuk 
terbanyak berada disekitar pukul 17.01 - 17.30 yaitu sebanyak 74 kendaraan dan yang paling sedikit jumlah kendaraan yang masuk berada pada pukul 13.01 - 13.30 yaitu sebanyak 15 kendaraan.

Untuk jumlah kendaraan yang keluar terbanyak berada disekitar pukul 19.31 - 20.00 WIB yaitu sebanyak 81 kendaraan dan yang paling sedikit jumlah kemdaraan yang keluar berada pada pukul $09.31-10.00$ WIB yaitu sebanyak 12 kendaraan.

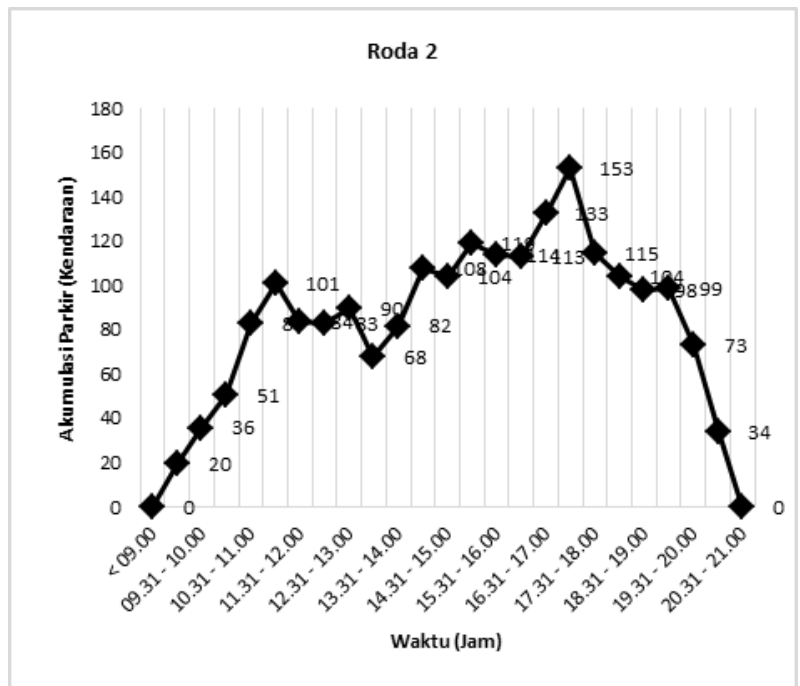

Gambar 1. Hubungan Waktu dan Akumulasi Parkir

Grafik 1 adalah hubungan waktu Parkir dan Akumulasi parkir. Akumulasi parkir kendaraan sepeda motor terlihat bahwa pada pengunaan ruang parkir yang terbesar berada pada pukul $17.31-18.00$ yaitu sebanyak 153 kendaraan dan terkecil pada pukul $09.31-10.00$ sebesar 20 kendaraan.

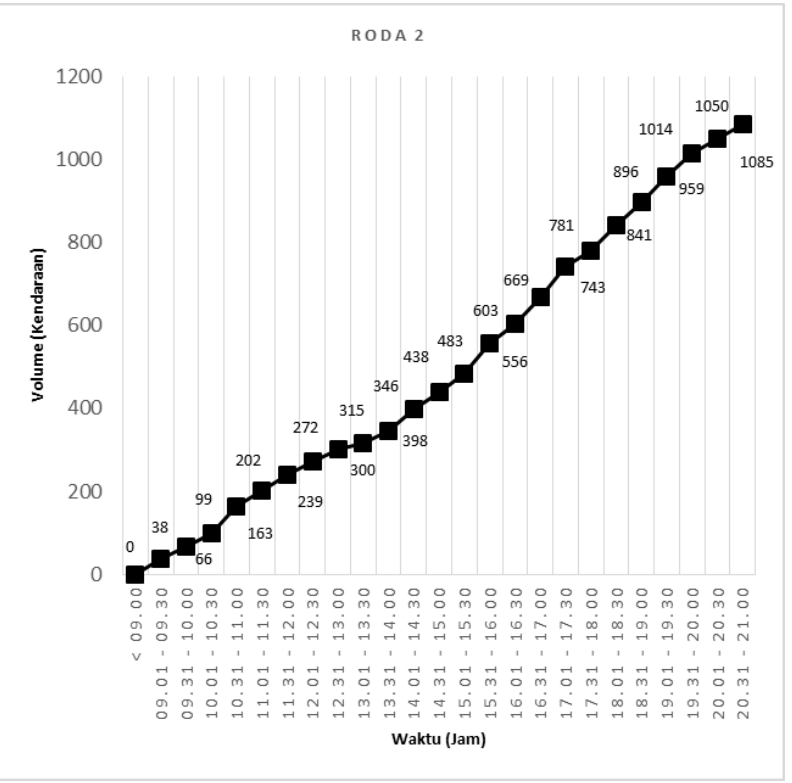

Gambar 2. Hubungan Waktu dan Volume Parkir
Grafik 2 adalah hubungan waktu Parkir dan volume parkir. Total volume parkir kendaraan sebesar 1085 kendaraan.

Volume parkir kendaraan mencapai lebih dari $50 \%$ sebanyak 1085 kendaraan (didapat dari $1085 * 50 \%$ ) = 543 kendaraan, yang dimulai pada pukul $16.01-16.30$ WIB.

\subsection{Parking Turn Over}

Untuk melihat tingkat pemakaian setiap ruang parkir dibutuhkan data yang lebih lengkap, namun secara keseluruhan tingkat pemakaian ruang parkir dapat dihitung dengan membagi total kendaraan parkir selama sehari dengan jumlah ruang parkir yang tersedia atau kapasitas parkir.

Adapun luas lahan parkir dalam kajian ini adalah: Ukuran petak parkir sesuai Manual Kapasitas Jalan Indonesia (MKJI) adalah :

- Ukuran Petak Parkir untuk Sepeda motor $=0,75 \times 2 \mathrm{~m}^{2}$

- Luas Lahan Parkir yang Tersedia untuk Sepeda motor $=293 \mathrm{~m}^{2}$

- Jumlah petak parkir = Luas lahan parkir Sepeda motor / ukuran petak untuk sepeda motor

$$
\begin{aligned}
& =278 \mathrm{~m}^{2} / 0,75 \times 2 \mathrm{~m}^{2} \\
& =\mathbf{1 8 5} \text { petak parkir }
\end{aligned}
$$

\begin{tabular}{|c|c|c|c|c|c|c|}
\hline Waktu & $\begin{array}{l}\text { Volume } \\
\text { Parkir }\end{array}$ & $\begin{array}{l}\text { Akumulasi } \\
\text { Parkir }\end{array}$ & $\begin{array}{l}\text { Lama } \\
\text { (Jam) }\end{array}$ & $\begin{array}{c}\text { Jumlah } \\
\text { Petak } \\
\text { Parkir }\end{array}$ & $\begin{array}{c}\text { Tingkat } \\
\text { Pergantian }\end{array}$ & $\begin{array}{c}\text { Tingkat } \\
\text { Penggunaan } \\
(\%)\end{array}$ \\
\hline & 1 & 2 & 3 & 4 & $5=(1) /(4)$ & $6=(2) /(4) * 100$ \\
\hline $09.00-10.00$ & 66 & 12 & 1 & 185 & 0,3568 & 6,49 \\
\hline $10.01-11.00$ & 97 & 32 & 1 & 185 & 0,5243 & 17,30 \\
\hline $11.01-12.00$ & 76 & 54 & 1 & 185 & 0,4108 & 29,19 \\
\hline $12.01-13.00$ & 61 & 21 & 1 & 185 & 0,3297 & 11,35 \\
\hline $13.01-14.00$ & 46 & 17 & 1 & 185 & 0,2486 & 9,19 \\
\hline $14.01-15.00$ & 92 & 44 & 1 & 185 & 0,4973 & 23,78 \\
\hline $15.01-16.00$ & 118 & 78 & 1 & 185 & 0,6378 & 42,16 \\
\hline $16.01-17.00$ & 113 & 46 & 1 & 185 & 0,6108 & 24,86 \\
\hline $17.01-18.00$ & 112 & 76 & 1 & 185 & 0,6054 & 41,08 \\
\hline $18.01-19.00$ & 115 & 61 & 1 & 185 & 0,6216 & 32,97 \\
\hline $19.01-20.00$ & 118 & 81 & 1 & 185 & 0,6378 & 43,78 \\
\hline $20.01-21.00$ & 71 & 69 & 1 & 185 & 0,3838 & 37,30 \\
\hline Total & 1085 & 591 & 12 & & 5,8649 & \\
\hline
\end{tabular}

Tabel 3 Parkir Turn Over Kendaraan

Sumber : Analisis Data, 2017

Pada Tabel 3 diatas terlihat bahwa sejak pukul 19.01 sampai dengan pukul 20.00, parking trun over per petak parkir selama 1 jam adalah sebesar 0,6378. Hal ini berarti bahwa setiap petak parkir selama 1 jam, rata rata hanya ditempati oleh 0,6378 kendaraan.

Pada tabel ini juga terlihat bahwa tingkat penggunaan lahan parkir pada pukul 19.01 - 20.00 hanya sekitar $43,78 \%$. Hal ini berarti bahwa hanya $43,78 \%$ dari 
total parkir yang digunakan oleh kendaraan, sisanya $(56,22 \%)$ dalam keadaan kosong.

Berdasarkan hasil analisis akumulasi kendaraan dan tingkat penggunaan lahan parkir diketahui bahwa kapasistas parkir masih mencukupi,namun permasalahan dilapangan adalah pengaturan parkir yang relatif kurang baik sehinga pemanfaatan lahan parkir yang tidak optimal, terutama tata latak parkir dan sirkulasi kendaraan pada lahan parkir, hal ini sering terjadi pada jam sibuk (Sabtu malam).

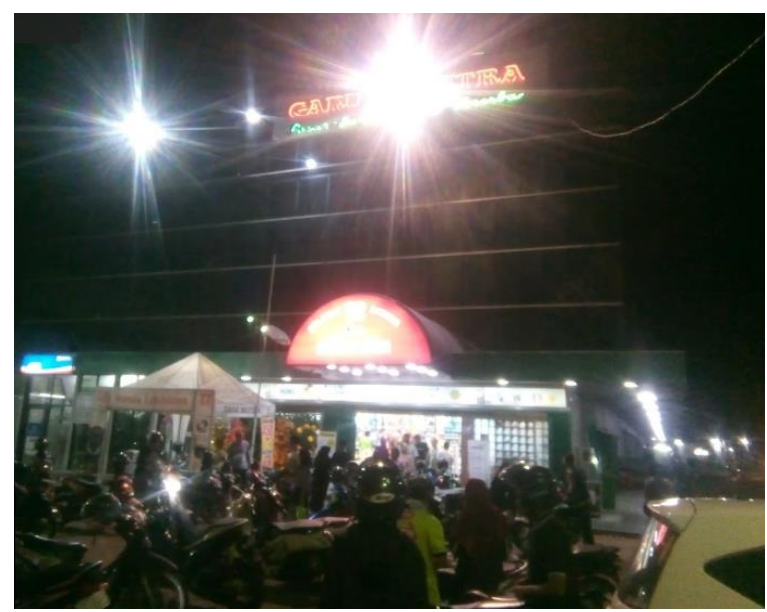

Gambar 3. Kondisi Parkir Garuda Mitra Pada Jam Sibuk (Sabtu malam)

\section{KESIMPULAN}

Berdasarkan analisis di atas, studi ini dapat disimpulkan sebagai berikut :

1. Durasi parkir sepeda motor dominan selama $0-30$ menit dengan jumlah kendaraan 654 kendaraan, dan kendaraan yang parkir melebihi 2 jam hanya 11 kendaraan.

2. Volume total kendaraan yang parkir selama satu hari sebesar 1.085 kendaraan dengan pendapatan parkir sebesar Rp. 1.085 .000

3. jumlah kendaraan yang masuk terbanyak berada disekitar pukul 17.01 - 17.30 yaitu sebanyak 74 kendaraan dan jumlah kendaraan yang keluar terbanyak berada disekitar pukul 19.31 - 20.00 yaitu sebanyak 81 kendaraan.

4. Berdasarkan akumulasi parkir diketahui bahwa penggunaan ruang parkir yang terbesar berada pada pukul 17.31 - 18.00 yaitu sebanyak 153 kendaraan dengan jumlah volume parkir dalam seharai sebesar 1.085 kendaraan.

5. Tingkat penggunaan lahan parkir terbesar pada pukul 19.01 - 20.00 sekitar 43,78\% dari kapasitas parkir yang tersedia hal ini berarti masih mencukup.

6. Permasalahan dilapangan adalah pengaturan parkir yang relatif kurang baik sehinga pemanfaatan lahan parkir yang tidak optimal, terutama tata latak parkir dan sirkulasi kendaraan pada lahan parkir.

\section{Ucapan Terima Kasih}

Terima kasih disampaikan kepada semua pihak yang telah terlibat baik langsung maupun tidak langsung sehingga makalah ini telah selesai dan dapat di publikasikan.

\section{Daftar Pustaka}

Dir. Jend. Bina Marga, 1997, Manual Kapasitas Jalan Indonesia, Jakarta.

Muktyarso A. W., Herijanto W., 2018, Perencanaan Gedung Parkir RSUD dr. Soetomo Surabaya, Jurnal Teknik ITS, Vo, 7 No. 2, Institut Teknologi Surabaya, Surabaya.

Novier A., Simanjuntak G., Wicaksono Y.I., Indriastuti A. K., 2015, Analisis Kebutuhan Ruang Parkir Paragon Mall Semarang, Jurnal Karya Teknik Sipil, Vol 4, No.4, Undip, Semarang.

Sholikhin R., Mudjanarko S.W., 2017, Analisis Karakteristik Parkir di Satuan Ruang Parkir Pasar Larangan Sidoarjo, Engineering and Sains Journal, Vol.1, No.2, UMAHA, Surabaya.

Tamin, Ofyar Z, 2008 Perencanaan, Permodelan, dan Rekayasa Transportasi Teori, Contoh Soal dan Aplikasi, Institut Teknologi Bandung, Bandung.

Taruno H. T., 2017, Evaluasi Kebijakan Pengelolaan Parkir Studi Kasus Kota Semarang, Journal of Governance, Vol. 2, No. 2, Universitas Sultan Ageng Tirtayasa, Banten.

Yuda M. R., 2015, Studi Optimalisasi Fasilitas Parkir di Fakultas Keguruan Ilmu Pendidikan (FKIP) Universitas Lampung, Jurnal Rekayasa Sipil dan Desain, Vol. 3 No. 3, Universitas Lampung, Lampung. 